\title{
Media Pembelajaran Berbasis Web pada Mata Kuliah Biologi Sel: Kajian Dari Aspek Validitas
}

\author{
Trisna Amelia ${ }^{1}$, Nurul Asikin ${ }^{2}$ \\ Pendidikan Biologi, FKIP, Universitas Maritim Raja Ali Haji, Tanjungpinang, Indonesia
}

Pengiriman: 6 November 2017; Diterima: 3 Maret 2018; Publikasi: Maret 2018

\begin{abstract}
Cell biology is one of the subjects that is difficult because the object of study is microscopic so that it can not be observed directly. A valid learning media is required to visualize microscopic material being sucked. Media learning developed in this research is a web-based learning medium that can provide visualisation of research objects in the form of video, image and link articles relevant to the material. This research and development adopted the Borg and Gall Development Model (1984). Web-based Learning media on cell biology courses is judged to be valid on aspects of web-based media and material aspects.
\end{abstract}

Keywords: Web-based Learning Media, cell biology, validity aspects

\begin{abstract}
ABSTRAK: Biologi Sel merupakan salah satu mata kuliah yang sulit karena objek kajiannya miksroskopis sehingga tidak dapat diamati langsung. Diperlukan adalanya media pembelajaran yang valid untuk memvisualisasikan materi yang mikroskopik tersebug. Media pembelajaran dikembangkan dalam penelitian ini adalah media pembelajaran berbasis web yang dapat menyediakan visualisasi objek kajian dalam bentuk video, gambar dan link artikel yang relevan dengan materi. Penelitian dan pengembangan ini mengadopsi model pengembangan Borg and Gall (1984). Media pembelajaran berbasis web pada mata kuliah Biologi Sel dinilai valid pada aspek media berbasis web dan aspek materi.
\end{abstract}

Kata Kunci: Media Pembelajaran Berbasis Web, Biologi Sel, Aspek Validitas

*Penulis Korespondensi:

Alamat surel: trisna.amelia@umrah.ac.id 


\section{PENDAHULUAN}

Biologi Sel merupakan salah satu mata kuliah inti dalam struktur Kurikulum Berbasis Kompetensi (KBK) Program Studi Pendidikan Biologi, Fakultas Keguruan dan Ilmu Pendidikan (FKIP) UMRAH yang mengacu pada Kerangka Kualifikasi Nasional Indonesia (KKNI). Mata kuliah ini merupakan salah satu mata kuliah yang dianggap sulit oleh mahasiswa. Hal ini terbukti dengan rendahnya pemahaman konsep mahasiswa untuk materi kuliah Biologi Sel. Sulitnya mahasiwa memahami konsep biologi sel bisa disebabkan oleh beberapa faktor. Faktor pertama adalah dari konsep biologi sel itu sendiri yang kebanyakan adalah konsep yang abstrak. Kajian biologi sel membahas mengenai struktur dan fungsi sel prokaryotik dan eukaryotik, khususnya makromolekul, membran dan organel. Objek kajian ini merupakan materi mikroskopik yang tidak bisa diamati langsung, namun memerlukan alat bantu dengan serangkaian prosedur laboratorium.

Kajian tentang sel ini menuntut kemampuan dosen untuk menyajikan konsep biologi sel menjadi konkrit dan merancang skenario pembelajaran yang tepat sehingga mahasiswa bisa melakukan aktivitas belajar dengan mengeksplorasi informasi konkrit tentang konsep tersebut. Masalah kedua yang dihadapi pada perkuliahan biologi sel yaitu dosen belum mampu untuk menerapkan pembelajaran yang diharapkan. Keterbatasan instrumen laboratorium dan media pendukung lainnya menjadi salah satu kendala yang dihadapi dosen. Selain itu, faktor mahasiswa juga menjadi kendala untuk mencapai pemahaman konsep biologi sel, yaitu mahasiswa kurang memiliki motivasi belajar, serta kemampuan awal mahasiswa yang tidak seragam. Semua permasalahan ini kemudian bermuara pada rendahnya penguasan konsep mahasiswa pada mata kuliah biologi sel.

Sebagai upaya penyelesaian masalah penguasaan konsep, perlu ada solusi yang tepat sehingga tujuan perkuliahan dapat dicapai. Perubahan paradigma pembelajaran perlu diperhatikan dalam hal ini, yaitu dosen berperan sebagai fasilitator, mediator dan motivator, sementara peran mahasiswa sebagai subjek pembelajaran harus menempatkan mereka sebagai aktor utama yang berperan aktif dalam proses perkuliahan. Proses perkuliahan harus dirancang menurut prinsip student-centered learning. Dalam kaitannya dengan mata kuliah Biologi Sel yang kaya akan konsep yang abstrak, diperlukan media pembelajaran yang sesuai sehingga mahasiswa bisa aktif dan termotivasi untuk mengeksplorasi materi perkuliahan. Sesuai dengan kondisi sarana dan prasarana perkuliahan di Program Studi Pendidikan Biologi (khususnya keterbatasannya sarana laboratorium/praktikum), maka perlu dipilih media pembelajaran yang memungkinkan mahasiswa terpapar pada dunia biologi sel tanpa perlu menunggu untuk bisa melakukan pengamatan langsung dengan instrumen laboratorium.

Penggunaan media pembelajaran merupakan salah satu cara yang diharapkan dapat membuat mahasiswa lebih mudah memahami konsep-konsep biologi yang dipelajari salah satunya berkaitan tentang Biologi Sel. Media pembelajaran yang digunakan dipilih secara tepat dan disesuaikan dengan konten (isi) dari setiap mata kuliah. Media pembelajaran yang digunakan dapat memberikan pengalaman bagi mahasiswa dalam belajar. Mahasiswa yang hanya mendengar dapat berbeda persepsinya dengan mahasiswa yang mendengar sekaligus melihat benda tersebut. Oleh karena itu, diperlukan suatu media yang dapat mempermudah mahasiswa menerima konsep yang disajikan dengan harapan dapat meningkatkan hasil belajar. Salah satu upaya untuk menyamakan persepsi sekaligus meningkatkan pemahaman konsep tentang Biologi Sel adalah dengan media pembelajaran berbasis web.

Seiring dengan kemajuan di bidang teknologi informasi dan komunikasi, maka dunia 
pendidikan juga telah banyak yang memanfaatkan web sebagai media pembelajaran. Melalui media pembelajaran berbasis web materi pembelajaran dapat diakses kapan saja dan dari mana saja, di samping itu materi juga dapat diperkaya dengan berbagai sumber belajar termasuk multimedia. Selain itu media pembelajaran berbasis web dilengkapi dengan beberapa fasilitas yang dapat kita kombinasikan penggunaannya untuk mendukung proses pembelajaran, antara lain forum diskusi, chat, penilaian online, dan sistem administrasi.

Univeritas Maritim Raja Ali Haji (UMRAH) telah memiliki Pusat Data sendiri yang disebut Mobile Data Center yang merupakan upaya akselerasi teknologi informasi dan komunikasi dengan pengembangan berbagai hal seperti jaringan, server, sistem informasi dan bandwidth akses internet. Kondisi real yang di temukan pada pra penelitian menunjukkan bahwa 1) Fasilitas yang dimiliki UMRAH berupa jaringan internet berbasis wifi tersedia di semua jurusan; 2) penggunaan internet dan terutama penerapan e-learning belum berjalan secara optimal; 3) Proses pembelajaran dengan menggunakan media pembelajaran berbasis web belum dimanfaatkan secara maksimal. Berdasarkan latar belakang tersebut, maka perlu dilakukan penelitian yang berjudul Pengembangan Media Pembelajaran berbasis Web pada Mata Kuliah Biologi Sel untuk Mahasiswa Pendidikan Biologi.

Pembelajaran berbasis Web adalah suatu kegiatan pembelajaran yang memanfaatkan media situs (website) yang bias diakses melalui jaringan internet. Pembelajaran berbasis Web atau yang dikenal juga dengan Web Based Learning, merupakan salah satu jenis penerapan pembelajaran elektronik (Elearning). Atau dapat juga dikatakan sebuah pengalaman belajar dengan memanfaatkan jaringan internet untuk berkomunikasi dan menyampaikan informasi pembelajaran.Internet merupakan jaringan yang terdiri atas ribuan bahkan jutaan komputer, termasuk di dalamnya jaringan lokal, yang terhubungkan melalui saluran (satelit, telepon, kabel) dan jangkauanya mencakup seluruh dunia. Internet memiliki banyak fasilitas yang dapat digunakan dalam berbagai bidang, termasuk dalam kegiatan pendidikan. Fasilitas tersebut antara lain: email, Telnet, Internet Relay Chat, Newsgroup, Mailing List (Milis), File Transfer Protocol (FTP), atau World Wide Web (WWW) (Anwas, 2013).

\section{METODE PENELITIAN}

Pengembangan produk pada penelitian ini dilakukan dengan mengacu pada model pengembangan Borg and Gall (1984). Pengembangan dilaksanakan sampai pada tahap kelima dari sepuluh langkah keseluruhan prosedur pengembangan yang dilakukan. Kelima tahap tersebut yaitu Research \& Information Collecting (Penelitian \& Pengumpulan Informasi), Planning (Perencanaan), Development Preliminary Form of Product (Pengembangan Produk Awal), Preliminary Field Test and Product Revision (Uji Coba Terbatas dan Revisi Produk), dan Main Field Test (Uji Coba Utama) (Borg \& Gall, 1984).

Untuk aspek validitas, instrumen yang digunakan berupa angket validasi media pembelajaran berbasis web. Data yang diperoleh berupa isian angket mengenai validitas media berbasis web yang diperoleh dari 2 ahli. Penilaian yang diberikan ahli (pakar) terhadap media pembelajaran berbasis web dilakukan terhadap 2 aspek berikut.

\section{a. Aspek media (web-based)}

Aspek ini berkenaan dengan kriteria media berbasis-web yang terdiri dari aspek usability, aspek functionality, dan aspek komunikasi visual.

\section{b. Aspek materi}


Aspek ini berkenaan dengan desain media, isi materi, dan bahasa yang digunakan..

\section{HASIL DAN PEMBAHASAN}

Data validitas media pembelajaran berbasis web diperoleh dari kuisioner tertutup dalam bentuk angket. Validasi media berbasis web dilakukan oleh dua orang validator yang terdiri dari ahli media dan ahli materi. Hasil penilaian media pembelajaran berbasis web dari ahli media disajikan pada Tabel 1 berikut.

\section{Tabel 1. Hasil Penilaian Ahli Media}

\begin{tabular}{clcc}
\hline No & $\begin{array}{c}\text { Kriteria } \\
\text { Media }\end{array}$ & $\begin{array}{c}\text { Rata- } \\
\text { Rata } \\
\text { Skor }\end{array}$ & Kategori \\
\hline 1 & $\begin{array}{l}\text { Aspek } \\
\text { Usability }\end{array}$ & 3,14 & Valid \\
2 & $\begin{array}{l}\text { Aspek } \\
\text { Functionality }\end{array}$ & 3,50 & $\begin{array}{c}\text { Sangat } \\
\text { Valid }\end{array}$ \\
3 & $\begin{array}{l}\text { Komunikasi } \\
\text { Visual }\end{array}$ & 3,00 & Valid \\
\hline $\begin{array}{l}\text { Rata-Rata Seluruh } \\
\text { Aspek }\end{array}$ & $\mathbf{3 , 2 1}$ & Valid \\
\hline
\end{tabular}

Ditinjau dari aspek Usability media pembelajaran berbasis web dikategorikan valid $(3,14)$. Aspek Usability mengacu pada kemudahan dalam penggunaan. Kriteria dalam setiap aspek terdiri dari menu dalam media website mudah untuk dipahami, tulisan teks yang digunakan pada menu dalam website mudah dipahami dan kontras dengan warna background, menu yang dipilih dapat menampilkan halaman dengan cepat, website dapat diakses dengan mudah, alamat website yaitu http://biologisel.com, menggunakan kata yang mudah diingat dan sesuai dengan mata kuliah yang dipelajari yaitu bilogi sel, konten dalam website informatif, informasi yang disajikan dalam website up to date.

Ditinjau dari aspek Functionality media pembelajaran berbasis web dikategorikan sangat valid $(3,50)$. Aspek Usability mengacu pada berfungsi atau tidaknya setiap menu website yang di akses. Aspek Functionality dikategorikan sangat valid karena pada media pembelajaran berbasis web setiap menu pada website dapat di akses dan berfungsi dengan baik, dimulai dari menu navigasi utama, menu forum, menu $\log$ in, menu $\log$ out, menu profil user, menu untuk meng-edit informasi user, menu mengganti password, menu dalam evaluasi, menu hasil evaluasi, menu untuk mengunduh dan mengunggah materi, link video dan menu saran.

Ditinjau dari aspek komunikasi visual media pembelajaran berbasis web dikategorikan valid $(3,00)$. Aspek komunikasi visual mengacu pada tampilan visual dari website yang terdiri dari penggunaan bahasa yang mudah dipahami, pemilihan teks yang sesuai, desain tampilan website yang sederhana dan menarik, pemilihan warna yang tepat, kekontrasan warna tulisan dan background, tata letak (lay out) web sudah konsisten, pemilihan video dan gambar yang sesuai dengan materi.

Berdasarkan Tabel 1, hasil penilaian media pembelajaran oleh ahli media didapat rata-rata untuk seluruh aspek (aspek usability, aspek functionality, dan aspek komunikasi visual) yaitu 3,21, sehingga dikategorikan valid sebagai media pembelajaran berbasis web. Media pembelajaran berbasis web yang valid tersebut dapat membantu mahasiswa dalam memahami konsep-konsep materi khususnya materi pada mata kuliah Biologi Sel. Penggunaan media pembelajaran berbasis web dapat dijadikan sebagai media untuk mendukung proses belajar mahasiswa (Neo et al., 2011).

Hasil penilaian media pembelajaran berbasis web dari ahli materi disajikan pada Tabel 2 berikut.

Tabel 2. Hasil Penilaian Ahli Materi

\begin{tabular}{clcc}
\hline No & Kriteria Media & $\begin{array}{l}\text { Rata- } \\
\text { Rata } \\
\text { Skor }\end{array}$ & Kategori \\
\hline 1 & $\begin{array}{l}\text { Desain } \\
\text { Pembelajaran }\end{array}$ & 3,50 & Valid \\
2 & $\begin{array}{l}\text { Isi materi } \\
\text { (konten) }\end{array}$ & 3,43 & Valid
\end{tabular}




\begin{tabular}{|c|c|c|}
\hline $3 \begin{array}{l}\text { Bahasa dan } \\
\text { komunikasi }\end{array}$ & 3 & Valid \\
\hline $\begin{array}{c}\text { Rata-Rata Seluruh } \\
\text { Aspek }\end{array}$ & $\mathbf{3 , 3 1}$ & Valid \\
\hline
\end{tabular}

Validasi media pembelajaran berbasis web yang dilakukan ahli materi ditinjau dari aspek desain pembelajaran, isi materi, dan bahasa dan komunikasi. Ditinjau dari aspek desain pembelajaran, media pembelajaran berbasis web dikategorikan valid $(3,50)$. Kriteria dalam setiap aspek desain pembelajaran terdiri dari kejelasan learning outcome, terdapat relevansi antara learning outcome dengan materi, relevansi antara penggunaan media dengan materi, materi disajikan secara sistematis, serta kemudahan dalam memahami isi materi.

Hasil validasi dari aspek isi materi (konten), media pembelajaran berbasis web dikategorikan valid $(3,4)$. Kriteria dalam setiap aspek isi materi (konten) terdiri dari acuan yang digunakan dalam materi pembelajaran sudah memadai. Untuk kriteria aktualisasi materi pembelajaran dalam media web sudah baik, sehingga memudahkan mahasiswa dalam memahami materi. Kriteria kejelasan media dalam menyampaikan dan memvisualisasikan materi sudah jelas, tetapi ada beberapa gambar dan video yang menggunakan bahasa inggris sehingga tergantung kepada kemampuan literasi bahasa inggris mahasiswa untuk memahami materi. Untuk kriteria muatan materi, cakupan materi dan kedalaman materi sudah sesuai dengan learning outcomess yang sudah di tentukan.

Hasil validasi dari aspek bahasa dan komunikasi, media pembelajaran berbasis web dikategorikan valid (3). Kriteria dalam setiap aspek bahasa dan kumunikasi terkait dengan penggunaan bahasa dan komunikasi yang bisa memudahkan mahasiswa dalam memahami materi. Aspek bahasa dan komunikasi terdiri dari bahasa yang digunakan sudah baik dan mudah dipahami, gaya bahasa yang komunikatif, dan redaksi dalam media pembelajaran sudah jelas.
Berdasarkan Tabel 2, hasil penilaian media pembelajaran oleh ahli materi didapat rata-rata untuk seluruh aspek (aspek desain pembelajaran, aspek isi materi (konten), dan aspek bahasa dan komunikasi yaitu 3, sehingga dikategorikan valid sebagai media pembelajaran berbasis web. Materi yang disajikan dalam media pembelajaran berbasis web dapat memberikan pemahaman konsep dan memotivasi mahasiswa dalam belajar (Cahyono, 2013; Neo et al., 2011).

\section{KESIMPULAN DAN SARAN}

Kesimpulan dalam tulisan ini adalah bahwa media pembelajaran berbasis web pada mata kuliah Biologi Sel yang dikembangkan dengan model Borg and Gall (1984) dinilai valid pada aspek media berbasis web dan aspek materi.

\section{UCAPAN TERIMAKASIH}

Penulis mengucapkan terima kasih kepada mahsiswa semester 5 tahun akademik 2017/2018 yang telah berpartisipasi dalam penelitian ini. Terima kasih juga disampaikan kepada Prof. Dr. Firdaus, LN., M.Si. (Program Studi Pendidikan Biologi FKIP Universitas Riau) dan Nerfita Nikentari, S.T., M.Cs. (Program Studi Teknik Informatika, Universitas Maritim Raja Ali Haji) yang telah bersedia menilai kelayakan media berbasis web yang dikembangkan. Terima kasih juga disampaikan kepada Direktorat Riset dan Pengabdian kepada Masyarakat, Kementerian Riset, Teknologi, dan Pendidikan Tinggi yang telah mendanai penelitian ini.

\section{DAFTAR PUSTAKA}

Anwas, O. M. (2013). Pemberdayaan Masyarakat di Era Global. Bandung: Alfa Beta.

Borg, W. R., \& Gall, M. D. (1984). Educational Research An Introduction. USA: Pearson Education Company.

Cahyono, K. (2013). Use of Web-based Interactive Media for Increase of Motivation and Learning Outcomes (Case Study at the University 
Abdurrahman Pekanbaru Riau). Journal Bina Praja, 5 (4), 243-252.

Neo, M., Neo, T.K., \& Yap, W.L. (2011). Engaging Students in a Interactive Web-Based Learning Environment Using Mayer's Design Principles: A Malaysian Experience. International Journal of Instructional Media, 38 (1), $37-45$. 